\title{
Ornithosymbols of the Kalmyk Language: Thanatological Aspect
}

\section{Ornitosímbolos de la lengua kalmyk: aspecto tanatológico}

\author{
Alexander B. Lidzhiev \\ Kalmyk State University named after B.B. Gorodovikov, Russia. \\ ORCID: https://orcid.org/0000-0002-9411-162X \\ Adieian G. Kukeev \\ Kalmyk State University named after B.B. Gorodovikov, Russia. \\ ORCID: https://orcid.org/0000-0002-6156-4534 \\ Michail U. Monraev \\ Kalmyk State University named after B.B. Gorodovikov, Russia. \\ ORCID: https://orcid.org/0000-0001-5219-233X \\ Nudlya Ch. Ochirova \\ Kalmyk State University named after B.B. Gorodovikov, Russia. \\ ORCID: https://orcid.org/0000-0002-5582-474X

\section{Zhanna A. Mukabenova} \\ Kalmyk State University named after B.B. Gorodovikov, Russia. \\ ORCID: https://orcid.org/0000-0002-7527-7990
}

*Correspondence

Email: ivannovadremova29@gmail.com
Cite as: 


\section{Summary}

This article is devoted to the ethnolinguistic study of the bird symbolism in the culture of Kalmyks and other Mongolian peoples. The work presents the main characteristics of bird symbolism, reflecting the most common images in the conceptions of Kalmyks, however, the main attention is paid to the thanatological aspect, this is due to the special specifics and a number of stereotypes in perception of some bird species. The most widespread thanatological symbol in the Kalmyk language and in the culture of the Mongol peoples dedicated to death is the raven and the owl. The objective of the work is to conduct an ethnolinguistic study of thanatological symbolism of birds in the Kalmyk culture, which is based on folklore and ethnographic material. The methodology of the study has been a complex method, which involves a comprehensive study of the material. The result of the work shows that traditionally, the Mongolian peoples have developed a set of symbols that are the most significant and revered. Signs and superstitions allow us to reconstruct the ethnic picture of the world and have a pronounced ethnocultural specificity, in which the experience of the people and stereotypes of ethnic consciousness are concentrated.

Keywords: birds, bird symbols, ornithosymbols, Kalmyks, Kalmyk culture, Mongolian culture.

\section{Resumen}

Este artículo está dedicado al estudio etnolingüístico del simbolismo de las aves en la cultura de los kalmyks y otros pueblos mongoles. El trabajo presenta las principales características del simbolismo de las aves, reflejando las imágenes más comunes en las concepciones de Kalmyks, sin embargo, la atención principal se presta al aspecto tanatológico, esto se debe a las especificidades especiales y a una serie de estereotipos en la percepción de algunas aves. especies. El símbolo tanatológico más extendido en la lengua kalmyk y en la cultura de los pueblos mongoles dedicados a la muerte es el cuervo y el búho. El objetivo del trabajo es realizar un estudio etnolingüístico del simbolismo tanatológico de las aves en la cultura kalmyk, que se basa en el folclore y el material etnográfico. La metodología del estudio ha sido un método complejo, que implica un estudio integral del material. El resultado del trabajo muestra que tradicionalmente, los pueblos mongoles han desarrollado un conjunto de símbolos que son los más significativos y venerados. Los signos y supersticiones nos permiten reconstruir el cuadro étnico del mundo y tienen una marcada especificidad etnocultural, en la que se concentran la experiencia de las personas y los estereotipos de la conciencia étnica.

Palabras clave: aves, símbolos de aves, símbolos de ornitho, kalmyks, kalmyk cultural, cultura mongol.

\section{Introduction}

This article is devoted to the ethnolinguistic study of the symbolism of birds in the culture of Kalmyks and other Mongolian peoples. Symbols have been used in the cultural space of mankind since ancient times, a person needs to symbolize the world around him and it is dictated by the fact that a symbol is an element of coding a cultural space. The meaningful basis of a symbol is an image or a sign, developed in the process of perceiving the surrounding reality, and embodies the stable value content of meaning. The work presents the main characteristics of the bird symbolism, reflecting the most common images in the conception of the Kalmyks, however, the main attention will be paid to the thanatological aspect in the conception of the Kalmyk and other Mongol peoples, and it is connected to special specificity and stereotypes in perception of some bird species.

\section{Problem statement}

The symbols of birds are of interest for interdisciplinary research, as they are at the intersection of different fields of science, such as: linguistics, cultural studies, ethnology, psychology. The study of symbolism from the standpoint of ethnolinguistics is relevant, as symbols have a 
pronounced national and cultural characteristic and are a reflection of the ethnolinguistic picture of the world. Symbolism has a dual character, as it contains meaning, i.e. concept, meaning and idea, as well as a specific object, or perceived image. For instance, any image is an example of ambivalence "any symbol can have at least two opposite interpretations that must merge in order for it to acquire full meaning" (Benois, 2006, p. 46). Such an example can serve a magpie, e.g. Slavic folklore shows its impure nature and demonic, harmful functions, and, on the other hand, as messengers and prophets (Tolstoy, 1995-2012). A symbol is a concept close to the image, which has national specificity and a semantic connection between an object and an abstract element of its content, the main feature of which is the ability to represent ancient images, or archetypes.

\section{Research Questions}

Ornithological symbols in their main characteristics coincide with any other symbols; as a rule, they include universality and individuality. It should also be noted that the symbol is closely related to mythology "there are many ideas about the same object or phenomenon, which in the conditions of modern logical thinking are perceived as figurative or metaphorical" (Tolstoy, 1990, p. 50).

This work is devoted to an ethnolinguistic study of bird perception's stereotypesin the traditional culture of Kalmyks and other Mongolian peoples. The work examines the symbolic signs of birds, lexemes and paroemias, collected on the material of the Kalmyk and other Mongolian languages. Since ancient times, a person has been using symbols to nominate the world around him, as a symbol is a specific element of the coding of a cultural space. The ornithosymbols, which are presented in the work, reflect the most common images in the ideas of the Kalmyk people. The ethnolinguistic study of ornithonyms and their symbolism in the Kalmyk language are of considerable interest, which determines the relevance and scientific novelty of the presented work. The need to give the main characteristics of bird symbolism is also relevant, because the symbolism is as ancient as any other symbol that has been present in human life since ancient times.

\section{Purpose of the Study}

Birds occupy an important place in the culture of many peoples, each ethnic group has its own ideas about the image of birds, these images help to understand and comprehend the worldview and picture of the world of these peoples. This work is devoted to the ethnolinguistic study of thanatological symbolism of birds in the culture of Kalmyks, which is based on folklore and ethnographic material. The relevance lies in the fact that ornithosymbols were not previously an object of special research and were on the periphery of scientific research in Mongolian studies. The work is based on the study of vocabulary and phraseological units, or texts of the so-called "small genre", this is due to the fact that in the culture of Kalmyks there are a large number of paroemias, many of which are recorded in the literature and folklore of the Mongolian peoples. The main attention is paid to the study of the thanatological aspect of ornithosymbols, as various types of birds in the ideas of the people have their own symbolism, which can have both positive and negative connotations, that is reflected in language, folklore, literature and culture. Birds are often associated with certain features, these images are fixed and reflect different phenomena of reality. Ornithonyms are widely represented in folklore of the Kalmyks and other Mongolian peoples: in fairy tales, proverbs, sayings and other genres of folklore.

\section{Research Methods}

The methodological basis of the study was a systemic, or complex, method that involves a comprehensive study of the material, in relation to certain household, ethnographic realities, involving the study of facts and phenomena in all their diversity, which makes it possible to 
comprehensively study the problem. The collected material was considered on the basis of the principle of a systematic approach.

\section{Findings}

Since ancient times, people have treated birds with respect, many believed that they are of divine origin or are deities themselves, because birds symbolized belonging to the upper space. In the mythology of many peoples, there are plots in which a people, a tribe, a clan or an individual has an origin associated with birds, telling about their origin. So, for example, some Turkic peoples of Siberia, Khakass, Yakuts, Tofalars, Tuvinians associated their origin with the raven and considered him the main guardian deity, he was the assistant of the demiurge and was sent for a human soul (Burnakov, 2010, p. 346). In Slavic mythology about the creation of the world, there are legends associated with a duck and a loon, which are considered unclean and devilish birds (Gura, 1997, p. 667-668).

As a rule, in the views of many peoples, birds are divided into clean and unclean, or good and bad (Tolstoy, 1995-2012). For example, a swan is one of the most common images in mythology, folklore and literature. The Kalmyks and other Mongolian peoples considered the swan as a sacred bird, they treated it with great respect and superstitious fear. The swan was considered the most noble bird, it couldn't be hunted, and only people of noble birth could hunt, but ordinary people needed to follow certain rules to hunt for a swan, otherwise a misfortune could happen to the person and his family (Dushan, 2016, pp. 195-196). Some Mongolian families had a respectful attitude towards the swan; they worshiped the swan. And in autumn when swans were escorted to warm lands, and in spring, when they met, people made an offering of milk (Ochir, 2016, p.51).

The crane was a sacred bird, it was also impossible to hunt for it, touch their eggs and chicks, there was a belief that cranes were able to conjure, and the spell reached its goal (Dushan, 2016, p. 196-197), this could probably be due to the fact that, according to the beliefs, the cranes had their own patron spirits, the one who would kill the crane, the spirit of the crane would haunt that person (Khangalov, 1903, p. 211).

The Mongolian peoples considered the turpan as a sacred bird. They believed that the turpan was the embodiment of the Buddhist clergy: «änr šowun bolwal lamyn sümstä šowun» giž keldeg tul hawar yarč äjr šowun irhed gerin yazadyn saysür towž säähen huwcan ömsč ugtul $\gamma$ yn yosan kedeg they say «turpan is considered a bird with the soul of a llama», so when spring comes and turpans are back, you have to burn incense behind the house, to put on beautiful clothes, and it is called meeting' (Namjil, 2010, p. 161).

In addition to the swan, crane and turpan, the vulture belongs to the sacred birds. The Oirats believed that the vulture, like the turpan, was associated with the clergy, they called it gelen (Buddhist priest), this is due to the lifestyle of a bird, which, like a Buddhist priest, feeds on alms, as it was believed that the vulture does not get food itself , but feeds on carrion. Leaving the dead body, the Oirats watched if the vulture arrived first, it was considered a good sign (Erdenebold, 2012, p. 78).

According to the Oirat's beliefs, a pigeon belongs to the sacred birds and cannot be killed: kögelžirgen bolwal ödr bol $\gamma o n$ maani toolž bäädeg šowun giž keldeg tul tüünig alwal kilnctä giž üzdeg 'they say that a pigeon is a bird that seems to read maani (prayer) every day that's why a killing a pigeon is considered a sin' (Namjil, 2010, p. 161). The Slavs have a similar ban on killing a pigeon, you cannot harm it and eat it, because its violation is considered a sin and entails negative consequences (Gura, 1997, p. 612-613). 
Ornithosymbols associated with particular images of various species of birds are important in the people's culture, as they can differ in the variability of their content and expression.

For example, the raven among the Oirats is an ominous bird, the chthonic nature of which appeared in its connection with the underworld - with the dead world, the souls of sinners and the underworld, as well as with underground treasure (Tolstoy, 1995-2012). However, they also considered killing a raven a bad omen (Erdenebold, 2012, p. 129), because it was believed: kerä alhla kezäd hoosn 'if you kill a raven it will always be empty'. This may be due to the fact that in the mythology of the neighboring peoples of Southern Siberia, the raven was a guardian deity, belonged to the demiurges and was sent for the soul of a person (Burnakov, 2010, p. 346).

Typically, one of the main functions of birds is bringing news. This is obviously due to the fact that birds are given a special role and certain qualities, as a rule, they are given a prophetic gift and are credited with participating in the fate of people, warn them, etc. (Propp, 2000, p. 196). The bird was considered a mediator between the worlds, upper and lower, as it is a symbol of the "other" world, personifies the receptacle of souls, acts as a courier between the world of the living and the dead, it is a messenger of the future (Kurashkina, 2018, p. 118). As a mediator between the upper and lower worlds, the bird is a symbol of the other world and eternity. As a receptacle for souls, the bird is a symbol of the unity of the beginning and the end. Figuring as a courier between the world of the living and the dead, the bird always symbolizes a sign, a prediction of the future (Makovsky, 2012 p. 184).

According to the ideas of many peoples, birds play the role of a messenger, they are a bearer of news, for many peoples this function is associated with a magpie, it represents dexterity, cunning, theft and spread of rumor (Ivanov, Toporov, 1997, p. 838). Kalmyks and other Mongolian peoples considered the appearance of a magpie as a good sign, whose chirping was interpreted as a harbinger of a joyful meeting, news or soon arrival of a guest (Erdenebold, 2012, p. 73), šaazya šagšarsar šin čimä olž sonsan 'when the magpie chirps, there will be news'; šaazya šagšarwas giič irnä 'if the magpie chirps, then a guest will come'. Dreams are one of the ways to transmit messages of the other world through birds, and the interpretation of dreams with the participation of birds was of particular importance. Therefore, if you saw a magpie in a dream, it was considered to the guests: šaazүa züüdelhlä zočn irnä (Dulam, 2009, p. 656) 'if you see a magpie in a dream, guests will come'.

Other birds could also bring messages, so the Oirats have a belief: "if you see a crow in your dream, wait for the news, if a woodpecker knocks on a tree, also to the message, and the appearance of a swallow in a dream promised especially interesting news" (Erdenebold, 2012, p. 73).

Positive symbolism among the Kalmyks was associated with swallows, its arrival means the coming of spring, if a swallow makes a nest in a yurt, then prosperity will come. If a swallow flies to the same place every year, this is a sign that happiness will settle in the house, it was forbidden to ruin the swallow's nest, otherwise a bad fate awaits a person (Basangova, 2018, p. 51). To see a swallow in a dream is a good omen: harada züïdelhlä sonin sääheg yumen duulna (Dulam, 2009, p. 656) 'if you see a swallow in your dream, it is believed that you will hear good news'. Mongolian peoples also believed that a woodpecker in a dream also symbolizes receiving messages: tojšur mod tojšež bäägä züüdelhlä keln medä irnä (Dulam, 2009, p. 656) 'if you dream that a woodpecker is knocking on wood, there will be news'. It is also connected with news if you see a duck in a dream: yanc nuүs züüdelhlä zakdal irnä (Dulam, 2009, p. 656) 'if only one duck dreams, a letter will come'.

However, in addition to good news in the culture of many peoples, there are birds that are bad messengers. Bad birds, for example, in the beliefs of the Slavs, usually include predatory and malignant birds, all crows (raven, crow, jackdaw, rook), magpies, kites and hawks and nocturnal birds (owl), as well as a sparrow, hoopoe, loon, duck, sandpiper and bat (Gura, 1997, p. 527). 
The Kalmyks and other Mongolian peoples usually refer to the crow as the ominous bird. The chthonic nature of the raven is connectedwith the underworld - with the dead world, the souls of sinners and the underworld, as well as with underground treasures [SA I, p. 435]. The chthonic connection can be dictated by the color of the bird, for example, among the Khakass, black is consistently associated with the chthonic world (Burnakov, 2010, p. 347), chthonism is characteristic not only of black crows, but also night owls, black woodpecker and some others (Tolstoy, 1995-2012), they are contrasted with white birds, as ominous and unclean.

Birds with negative semantics were considered bad messengers, or ominous. Among the Kalmyks, this status was possessed by the raven, which can foresee and determine the fate of people. The raven brings news from another world, according to popular beliefs these predictions are often negative. The Oirats believed that the raven predicts bad news; they called the raven «har muu amtai hemeen» 'a black bad soul'. According to the Oirats, a negative image is associated with its lifestyle "it is a wolf's companion and feeds on blood, therefore a raven is considered a bad bird" (Erdenebold, 2012, p. 74). Prophecies imply various misfortunes, troubles, death, etc. "If a raven flies close to the house and screams, then trouble will surely happen" (Burnakov, 2010, p. 346). According to the Buryats, a raven is considered a bad bird and its cry is a bad omen: "If a raven sits down on someone's house and shouts, it's for the worse. The owner must invite the shaman and sprinkle wine and tarasun, because the raven is considered the messenger of the big black zayans" (Khangalov, 1903, p. 208).

As a rule, nocturnal predators (owl) are classified as unclean (Tolstoy, 1995-2012), they are endowed with demonic features, in many traditions they are classified as "bad birds" that carry a threat or misfortune, they predict trouble (Ivanov, Toporov, 1997, p. 346). So, for example, in Slavic mythology, all night birds of the owl family belong to the ominous; their appearance near the house means death (Gura, 1997, p. 568). A similar attitude towards nocturnal birds (an owl) is noted among the Kalmyks, if it flew to the house or circles around it, then this is considered a bad omen, for example: uuli šowun duu yarhin sogsahla muu ior 'if you heard the cry of an owl, it's a bad omen'. A similar attitude is also noted by the Oirats: uuli šowun ashan bürül buyu söögər irž gerin həwid duuyarwal «muu yorta» giž üzdeg tul haž alh buiu kööž yowuldeg 'if an owl sits near the house late in the evening or at night and shouts, then, it is a bad sign,so it is necessary to shoot or drive away' (Namjil, 2010, p. 160).

The appearance of an owl is most often perceived as a harbinger of death in the family, therefore this omen is relevant in dreams: uuli šowun gerin üüdend dogydon züüdelhlä kümn ükh 'if you dream that an owl hoots near the door, this means the death of a person'. A similar negative attitude was noted in Russian culture towards the magpie "it was believed that if the magpie shouted on the roof of the house, then the dead man would be in the house" (Zinovieva, 2012, p. 85).

Although the goose in the Kalmyk culture does not belong to bad birds, however, negative emotions can be associated with it, so if a flock of swans or geese flies over the house and gets confused, or comes into disarrayfor no particular reason, then this is means a bad sign (Khangalov, 1903, p. 211).

Screaming poultry can serve as a bad omen, for example, a cackling chicken at night is considered a bad sign: söö dund taka duuyarwal «muu yorta yumn» giž üzdeg tul alž orkdag 'it is believed that if a chicken starts screaming in the middle of the night, it's a bad omen, so it must be killed' (Namjil, 2010, p. 161).

Dreams are perceived as information got through communication with the "other world", which understood as a kind of message through messengers, that are often birds. Therefore, a dream is considered a bad sign in which a cackling goose appears: yalun yanyanž züüdelhlä, küümn üknä, üy yašun bolh (Dulam, 2009, p. 656) 'if in a dream you see a cackling goose, it means the death of a person, bad times will come'. 
As mentioned above, among the Kalmyks, the turpan refers to the sacred birds and is the embodimentof the Buddhist clergy, it is believed that this bird has the soul of a lama (Buddhist priest), thus, the death of the turpan symbolizes the death of a clergyman: ägr šowun dalad unžz ükž züüdelwäs manž küms ükh beleg 'if in a dream a turpan fell into the ocean and died, the omen means the death of a mandzh (the lowest monastic degree among Kalmyk Buddhists)' (Dulam, 2009, p. 656).

The hoopoe was considered a bad bird among the Mongolian peoples. The harbinger of misfortune was considered a meeting with a hoopoe and a raven, whose images in the tradition of Mongol-speaking peoples are surrounded by an aura of negative meanings (Sodnompilova, 2009, p. 188). According to the Buryats, if the hoopoe begins to fly to someone's home, it is considered a bad omen. And if the hoopoe makes a nest in someone's house, lays eggs and begins to hatch chicks, then the owner needs to catch the bird in the nest and take it to the crossing of three roads, bury both the bird and the nest there, covering everything with earth (Khangalov, 1903, p. 208).

A symbolic connection with the souls of the dead is found in the image of an eagle: "the appearance of an eagle in a dream predicted [the news] the death of a person" (Erdenebold, 2012, p. 73). The motive of the eagle's connection with the "other" world can be demonstrated in the following example: bürged züüdelhlä üksen kümnə tuha bičig caasn irnə (Dulam, 2009, p. 656) 'if an eagle is dreamed, a letter (news) of a person's death will come'.

Some birds with negative semantics is obviously associated with their dark coloration. Because of their black color, they can be associated with the theme of death, illness or misfortune. For example, the following belief is associated with ablackbird among the Mongolian peoples, it is considered a bad omen to see a blackbird in a dream: har šowu zü̈̈delwäs ik öwčin olh 'if you see a blackbird in a dream, there will be a severe illness' (Dulam, 2009, p. 656). Such birds are often not associated with thanatological semantics, their connection with deadly symbolism is found at the level of diseases and misfortune.

\section{Conclusion}

The most common thanatological symbol in the Kalmyk language and in the culture of the Mongol peoples dedicated to death is the raven and the owl. The relationship of the raven with the kingdom of the dead is obviously associated with the black color, and the owl is like a nocturnal bird. In the context of general symbolism, birds are associated with the sky, and thus they act as mediators between the sky and the afterworld. Sometimes the idea of death can be associated with other birds such as an eagle and a goose. Other birds are not directly related to the theme of death, but can predict misfortune and illness. Of course, ornithological symbolism in the thanatological aspect is not limited by the specified list of birds, however, these are the most common images. The most frequent images of ornithosymbols of the Kalmyk language and other Mongolian languages are associated with other categories, as a rule, these are news, receiving any news, the arrival of guests, meeting with relatives, etc.

Ornithological symbolism is not limited by images of birds, nevertheless, this list is the most widespread and known not only in the culture and language of the Mongolian peoples, these ornithonyms are common and are included in the mythology of many peoples around the world.

Traditionally, the Mongolian peoples have developed a set of symbols that are the most significant and revered. For a long time, legends were formed about these symbols, which acquired national features, and in some cases they became omens and superstitions. Many omens and superstitions are outdated and not relevant, however, they allow us to reconstruct the naive picture of the world of the ethnos and have a pronounced ethnocultural specificity, in which the experience of the people and stereotypes of ethnic consciousness are concentrated. 


\section{Acknowledgments}

The study is performed under financial support of the Russian Foundation for Basic Research within project No. 19-012-00531 "Lexicon of material culture of the Kalmyk language: ethnolinguistic study".

\section{References}

Basangova, T.G. (2018). The crow in the Kalmyk folklore: signs, spell, fairy tale // News of the Dagestan State Pedagogical University. Social and human sciences, Vol. 12, No. 1, p. 3034

Benois, L. (2006). Signs, Symbols and Myths. Transl. from French A. Kalantarova. M.: Astrel: AST, $160 \mathrm{p}$.

Burnakov, V.A. (2010). The image of corvids in the Khakass worldview // Problems of history, philology, culture. Moscow-Magnitogorsk-Novosibirsk, No. 4, p. 346-362.

Dulam, S. (2009). Mongolian fortune-telling. Inner Mongolia People's Press Committee, Huhhot. $832 \mathrm{p}$.

Dushan, U. D. (2016). Selected Works. Elista: KIGI RAN, 376 p. (ManuscriptumOrientalica).

Erdenebold, L. (2012).Traditional beliefs of the Oirat-Mongols (late 19th - early 20th centuries). Ulan-Ude: Publishing house of the Buryat Scientific Center of the SB RAS, 196 p.

Gura, A.V. (1997). Symbols of animals in the Slavic folk tradition. M., 912 p.

Ivanov, V.V., Toporov, V.N. (1997). Birds // Myths of the peoples of the world:Encyclopedia. T. II.M., p. 346-349.

Khangalov, M. N. (1903). Balagansky collection. Fairy tales, beliefs and some rituals among northern Buryats. - Tomsk, 290 p.

Kurashkina, N.A. (2018). The main characteristics and types of ornithological symbols // Reports of the Bashkir University, Vol. 3, No. 1, p. 115-120.

Makovsky, M. M. (2012). Phenomenon of TABU in the traditions and in the language of the IndoEuropeans: Essence, forms, development. Ed. 4th. M.: Book House "Librokom", 280 p.

Namjil, T. (2010). Oirat-Mongolian religious-ritual culture. Urumqi, Xinjiang People's Publishing House, 457 p.

Ochir, A. (2016). Mongolian ethnonyms: questions of the origin and ethnic composition of theMongolian peoples, Elista: KIGI RAS, 286 p.

Propp, V.Ya. (2000). The historical roots of the fairy tale. M.: Labyrinth, 336 p.

Sodnompilova, M.M. (2009). Peace in the traditional worldview and practical activities of the Mongolian peoples. Ulan-Ude, $366 \mathrm{p}$.

Tolstoy, N.I. (1995-2012). Slavic antiquities. Ethnolinguistic dictionary: in 5 volumes. M.: International relations. 
Tolstoy, N.I. (1990). To the reconstruction of the semantics and functions of some Slavic pictorial and verbal symbols and motives // Folklore and Ethnography. Problems of reconstruction of the facts of traditional culture: Collection of scientific works. L.: Publishing house "Science", p. 50.

Zinovieva, E.I. (2012). Ornithonym magpie in the Russian language and culture: universal and national-specific, World of the Russian word. StPb, No. 4, p. 82-86. 